\title{
THE DEFINITION OF INVESTMENT AND THE ICSID CONVENTION: MATTERS ARISING UNDER THE NIGERIAN INVESTMENT PROMOTION ACT AND INTERNATIONAL INVESTIMENT LAW
}

\author{
Felix O. Okpe*
}

\begin{abstract}
This article contends that the omission to define investment in the Convention on the Settlement of Investment Disputes between States and Nationals of Other States (the ICSID Convention) has a trickledown effect on the Nigerian Investment Promotion Act (the NIPC Act), in the context of investment treaty law and arbitration. Its greatest impact is the relegation of the contribution to economic development element of the definition of "investment" to a backseat contrary to the purpose of the ICSID Convention. This article proposes a simple thesis: the omission to define investment in the ICSID Convention has fostered an amorphous definition of investment under the NIPC Act, thus creating uncertainty, irrelevance and ambiguity. The uncertainty is a potential problem in the conduct of foreign direct investment under the ICSID Convention. The article recommends a review of the definition of "investment" under the Act and the adoption of a definition that restricts foreign investment within the territory of Nigeria and makes acontribution to economic development its core element in line with the fundamental objective of the ICSID Convention.
\end{abstract}

Keywords: Nigerian Investment Promotion Act, Law and Development, Investment Law and ICSID Arbitration

DOI: https://dx.doi.org/10.4314/jsdlp.v8i2.9

\section{INTRODUCTION}

One of the misgivings expressed by some scholars and commentators about the ICSID Convention is the omission to define "investment"

* PhD (Aberdeen); Attorney at Law; Law Professor at Salmon P. Chase College of Law, Northern Kentucky University, USA. The usual caveat applies. The author may be reached at f.o.okpe@gmail.com 
with reference to the jurisdiction of the Center for Settlement of Investment Disputes (" the Center") under Article 25 (1) of the ICSID Convention. ${ }^{1}$ The history of the ICSID Convention and the circumstances leading to this omission hasbeen analysed elsewhere by this author. ${ }^{2}$ As a practical matter, the effect of the omitted definition of investment in the ICSID Convention continues to generate controversy. There have been unsuccessful attempts by scholars and arbitral tribunals to reach a consensus on the proper meaning to ascribe to the term. But, there is hope in the progressive development of this area of the law because the jurisprudence of the Center is still evolving.

The relevance of this article is underscored by what appears to be an amorphous definition of "investment" under the Nigerian Investment Promotion Act("NIPC Act"). ${ }^{3}$ The definition under the NIPC Act creates uncertainty in view of the lack of a precise definition of the term in the ICSID Convention, particularly in the context of international investment law and ICSID arbitration.

This matter is also important because of the unrestricted access to ICSID arbitration under Section 26(2)(b)(c) of the NIPC Act. Under these provisions, a foreign investor whose country is not a party to any investment treaty with Nigeria, but whose country is a signatory to the ICSID Convention can arbitrate claims against Nigeria under ICSID arbitration mechanism and rules. ${ }^{4}$ The NIPC Act also allows Nigeria and the foreign investor to elect ICSID arbitration. This access to ICSID arbitration by foreign investors in Nigeria makes the definition

1 Convention on the Settlement of Investment Disputes between States and Nationals of Other States (the ICSID Convention) opened for signature 18 March 1965. The Convention entered into force on 14 October 1966. The full text of the ICSID Convention, Regulations and Rules are available at $<$ https:// icsid.worldbank.org/ICSID/StaticFiles/basicdoc/CRR_English-final.pdf > accessed 18 September 2017.

2 See F. O. Okpe, "Endangered Element of ICSID Arbitral Practice: Investment Treaty Arbitration, Foreign Direct Investment and the Promise of Economic Development in Host States" (2014) 13 Richmond Journal of Global Law \& Business 217, 225-37.

3 Nigerian Investment Promotion Act, Chapter N117 (Decree No.16 of 1995) Laws of the Federation of Nigeria 2004 ("NIPC Act").

4 Southern Pacific Properties (Middle East) (SPP) Ltd. v Arab Republic of Egypt (ICSID Case No. ARB/84/3, Decision on Jurisdiction (N0.1) 27 November 1985) 3 ICSID Reports 101-130; See also K.U.K. Ekwueme, "Nigeria's Principal Investment Laws in the Context of International Law" (2005) 49 Journal of African Law 177, 199-200. 
of "investment" under the NIPC Act pertinent, with respect to potential investment claims against Nigeria. This potential is rife because Nigeriais host to substantial foreign investments, mostly in its oil and gas industry, arguably the mainstay of the Nigerian economy. Hence the need for Nigeria to be proactive in its international investment regime to reflect its expectation especially in view of the misgivings about the ICSID Convention on the definition of "investment" and Nigeria's volatile socio-political economy. ${ }^{5}$

The settlement of investment disputes within the framework of the Center is based on consent and request for arbitration. An ICSID tribunal lacks jurisdiction over investment treaty arbitration where the subject matter of the dispute is determined not to be an "investment". 6 The debate over the definition of "investment" under the ICSID Convention has created a dilemma for several arbitral tribunals established pursuant to the ICSID Rules.The amorphous definition of "investment" under the NIPC Act articleis an opportunity for Nigeria to come to grips with the ICSID Convention, reform its international investment regime and adopt a definition of "investment" that is more in line with the purpose of the ICSID Convention.

The article is divided intosixsections. Section 2 relies on case law and ICSID jurisprudence to analyse the relevance of the definition of "investment" under the ICSID Convention to lay the foundation for the article. Section 3 explores the attempt of the "Salini Criteria" to define "investment" under the ICSID Convention to set the stage for the discussion of the pertinent provision on the matter under the NIPC Act. Section 4 examines ambiguity and uncertainty of the definition of "investment" under the NIPC Act and its potential implications under international investment law and ICSID arbitration. The NIPC Act is the primary legislation for the conduct of foreign direct investment (FDI) in Nigeria in the absence of any applicable investment treaty. Section 5 articulates the recommendation to address the issue raised in this article. Section 6 concludes by calling for a review of the definition of investment under the NIPC Act that should bring the

5 See A. A. Asouzu, International Commercial Arbitration and African States: Practice, Participation and Institutional Development (Cambridge University Press, Cambridge 2001) 217 arguing that, "African States are not proactive in that they are mainly respondents in ICSID proceedings".

6 Nima M. Tabari, LexPetrolea and International Investment Law: Law and Practice in the Persian Gulf (Routledge, 2016) 106-114. 
definition in line with the fundamental underpinnings of the ICSID Convention.

\section{THE RELEVANCE OF THE DEFINITION OF INVESTIMENT IN ICSID ARBITRATION}

It may be argued that the jurisdiction of an arbitral tribunal within the framework of the ICSID Convention is determined by the view of the constituted tribunal on the definition of investment. The definition is the key to ICSID arbitration. The hypothesis on the relevance of the definition of aninvestment should not be construed as belittling other critical jurisdictional elements. All jurisdictional elements must be satisfied before an ICSID tribunal can assume jurisdiction over an investment dispute. However, unlike the other jurisdictional elements, there is no definition of "investment" in the ICSID Convention. Thus, arbitral tribunal usually attempts to define investment through an inquiry into the law or investment treaty that is applicable to the investment dispute. Generally, the purpose of this inquiry is to determine whether the transaction in issue qualifies as an "investment" in compliance with the jurisdictional requirements of Article 25 (1) of the ICSID Convention. If there is no "investment" within the meaning of the relevant provisions of the ICSID Convention, ICSID arbitration is not the proper medium to resolve the dispute. In as much as scholars have used a considerable amount of ink on how to define the term, in view of the omission in the ICSID Convention, and regardless of the consent clause, a protected investment must be determined, before an arbitral tribunal may assume jurisdiction in ICSID arbitration. ${ }^{7}$

The relationship between a definition of investment and the question of jurisdiction explains why Williams and Foot pointed out that " $[t]$ he notion of whether or not there is an investment for the purposes of ICSID Convention is undoubtedly fundamental." of the drafters of the ICSID Convention may be called into question for leaving the term undefined by placing it at the doorsteps of the consent

7 See Jeswald W. Salacuse, The Law of Investment Treaties (2nd edn, OUP 2015) 392-453.

8 D. A. R. Williams and S. Foote, "Recent Developments in the Approach to Identifying an 'Investment' Pursuant to Article 25(1) of the ICSID Convention" in C. Brown and K. Miles (eds), Evolution in Investment Treaty Law and Arbitration (Cambridge University Press, 2011) 42, 44. 
of the State parties and the investors on the one hand and the opportunity afforded by Article 25(4) of the Convention on the other. ${ }^{9}$ This is because, whether or not the reasons for the omission are laudable, there are still serious questions about the jurisdictional threshold of Article 25(1) of the Convention with respect to the definition of investment. Arbitral tribunals continue to differ on the issue whether a protected "investment" is in accordance with the parties' consent and applicable agreement within the framework of the ICSID Convention.

Notwithstanding the controversy the omission to define investment has generated, one arbitral tribunal has suggested that one of the advantages of the omission to define "investment" in the ICSID Convention is that it creates a flexibility that preserves the integrity of the term to allow for a progressive development of the definition of investment in the domain of international investment law. ${ }^{10}$ The view expressed by this arbitral tribunal offers some hope at reaching a consensus on the definition of investment in the future.

The development of the jurisprudence of ICSID arbitration is not there yet. There is not yet any substantive evidence, empirical or anecdotal, that the effect of Article 25(4) has stemmed the tide of inconsistency associated with the jurisprudence of ICSID arbitration on the definition of "investment". As two commentators rightly noted, the flexibility created by the omission "has led, perhaps inevitably, to piecemeal and sometimes inconsistent approaches to determining whether there is an investment as the term is used in Article 25 (1)."11

9 See Report of the Executive Directors on the Convention on the Settlement of Investment Disputes between States and National of other States (1965) para 27 available at < https://icsid.worldbank.org/ICSID/StaticFiles/basicdoc/partBsection02.htm > accessed 18 September 2017. para 27 which states: "No attempt was made to define the term "investment" given the essential requirement of consent by the parties, and the mechanism through which Contracting States can make known in advance, if they so desire, the classes of disputes which they would or would not consider submitting to the Center". See also ICSID Convention (n 1) Article 25(4) giving a State party the power to make an advance choice on the type of investment disputes to submit to ICSID arbitration.

10 Mihaly International Corporation $v$ Democratic Socialist Republic of Sri Lanka (ICSID Case No. ARB/00/2, Award, 15 March 2002) para 2 available at < http:/ /www.worldbank.org/icsid/cases > accessed 18 September 2017 para 33.

11 D. A. R. Williams and S. Foote (n 8) 47. 
In M.C.I Power Group L.C and New Turbine, Inc. $v$ Republic Ecuador ${ }^{12}$ on the definition of investment under the ICSID Convention, this arbitral tribunal held that a broad definition of "investment" is such that "the intangible assets of accounts receivable, the existence of an operating permit would fit that definition."13 The arbitraltribunal observed that the scope of the investment dispute and the legal consequences of the allegations of the State party and the investor should be held in abeyance until the merits of the investment disputes are submitted for adjudication. ${ }^{14}$

It should be noted that the SGS $v$ Philippines ${ }^{15}$ tribunal was met with sharp criticisms for adopting the same approach. ${ }^{16}$ In the ICSID arbitration, after assuming jurisdiction by rejecting a valid forum selection clause evident in the agreement between the State party and the investor, the arbitral tribunal gave effect to the same forum selection clause to stay proceedings to enable another forum todecide the merits of the contract claims. ${ }^{17}$ In adopting the definition of investment, the MCI tribunal passed an opportunity to contribute to a more acceptable definition of investment pursuant to the principles enshrined in the ICSID Convention. Instead, its definition of the termfurther contributed to the uncertainty arising from the lack of a clear definition of investment in the ICSID Convention.

The uncertainty over the definition of investment and the inconsistent approach of arbitral tribunal to the issue may have also led to a misunderstanding of the notion of investment as a means of direct economic development and global prosperity in developing countries. The need to spread international development to the global South is one of the most fundamental objectives of the ICSID Convention. The current system does not augur well with the motivation

12 M.C.I Power Group L.C and New Turbine, Inc. $v$ Republic of Ecuador (ICSID Case No. ARB/03/6, Award of 31 July 2007) available at< http://www.worldbank. org/icsid/cases > accessed 16 September 2017.

13 ibid para 164.

14 ibid para 163.

15 SGS SocieteGenerale de Surveillance S.A. $v$ Republic of the Philippines (ICSID Case No. ARB/02/6, Decision on Objection to Jurisdiction of 29 January 2004) available at< http://www.worldbank.org/icsid/cases >accessed 5 September 2017.

16 See generally Jude Antony, "Umbrella Clauses since SGS V Pakistan and SGS v Philippines - A Developing Consensus" (2014) 29 (4) Arbitration International 607-40.

17 Ibid. 
of developing countries in submitting investment disputes to ICSID arbitration.

For example, most developing countries, especially the African States, including Nigeria, participated and ratified the ICSID Convention by providing guarantees for the protection of foreign investments as host States for FDI in exchange of attracting requisite international capital for economic development. The motivation of African States in embracing the underpinnings of the ICSID Convention was eloquently stated by the Guinean representative during the negotiation of the Convention. The representative of Guinea observed that economic development could not be achieved without international capital. The Guinean official noted that countries would be unable to attract the needed capital in the absence of adequate guarantees for the protection of foreign investments. ${ }^{18}$

On his part, the Sierra Leone representative expressed optimism that African countries are likely to obtain the necessary foreign investments for economic development if they consent to the proposed ICSID arbitration. A representative of the World Bank during the negotiation of the ICSID Convention expressed the motivation of African countries this way: "I had expected a good and sympathetic discussion, but it was more constructive and more helpful than I dared to expect."19

After the African regional consultative meeting held in Addis Ababa, Ethiopia, during the negotiation of the ICSID Convention, the Executive Directors of the World Bank reported that no African country objected to the principles underlying the ICSID Convention. In fact, one delegate expressed the view that the proposed ICSID link with the World Bank "would give capital importing countries a greater sense of confidence". ${ }^{20}$ Distinguishing the doctrinal attitude of most Latin American States from African States on the proposed ICSID Convention, Asouzu reports that, because the latter has no doctrinal opposition to the concept of "investment" or investment arbitration as envisaged in the ICSID Convention, they are "willing to contribute to its development provided their interests are or will be recognized and protected." 21

18 History of the ICSID Convention: Documents Concerning the Origin and the Formulation of the Convention on the Settlement of investment Disputes between States and Nationals of Other States (Vol. II, Part 1, ICSID Publication 1968) 244. 19 ibid 298.

20 ibid 296-297.

21 A. A. Asouzu (n 5) 228. 
Despite the inconsistency inherent in ICSID arbitration on the definition of "investment", some arbitral tribunals recognize the connection between the protection of foreign investment and the purpose of international capital in their attempt to define"investment" in the context Article 25 of the ICSID Convention. Conversely, there are also notable examples where arbitral tribunals have rejected a consideration of contribution to economic development as an element altogether, in the process of defining "investment". In Amco Asia Corporation, Pan American Development Limited, PT Amco Indonesia $v$ Republic of Indonesia ${ }^{22}$ the investment dispute arose over the unlawful taking of foreign investment and cancellation of an international business license.

In 1968, an American company organized under the laws of the Republic of Indonesia entered into a Lease and Management Agreement with an Indonesian company under the guidance and approval of the Republic of Indonesia. Under this agreement, the American company undertook to invest more than US\$ 4 million in the construction and development of an hotel/office complex and to manage the same for a period of 30 years until 1999 under an agreed profit-sharing formula.

In April 1980, the Indonesian company forcefully took over the hotel and office complex. Thereafter, in July 1980 the Indonesian government revoked Amco's license to engage in business in Indonesia, thus denying the foreign company the benefits of the contract. Aggrieved by the action of the Republic of Indonesia, the American company commenced the first ICSID arbitration claiming damages for theunlawful taking of the hotel/office investment and cancellation of its business license to operate in Indonesia. The first tribunal agreed with the Claimant that the Republic of Indonesia violated international law for its failure to protect the investment of the American company. The arbitral tribunal was of the view that the Republic of Indonesia violated its obligation to protect foreign aliens against unlawful acts of its citizens.

On the definition of "investment" pursuant to the ICSID Convention, the Amco tribunal connected the protection of foreign investments to the interest of economic development regarding developing countries. Relying on the preamble of the ICSID Convention, this arbitral tribunal espoused the view that the protection of foreign

22 Amco Asia Corporation, Pan American Development Limited, PT Amco Indonesia v Republic of Indonesia (ICSID Case No. ARB/81/1, Decision on Jurisdiction of 25 September 1983) 1 ICSID Reports 400. 
investment is coextensive with the interest of economic development in developing countries with reference to the definition of "investment" under the ICSID Convention. ${ }^{23}$ The premise of the view of this arbitral tribunal in this respect may be criticized as myopic for being biased in favour of developing countries. Under the ICSID Convention, developed countries in Europe and North America may also be host States.Jackson declares that: "the United States is the largest foreign direct investor in the world and the largest recipient of foreign direct investment." 24 Still, it is contended that the reasoning and interpretation of this arbitral tribunalare more persuasive because it accords more with the underpinnings of the ICSID Convention.

The reasoning of the Amco arbitral tribunal is similar to the view of the arbitral tribunal in the ICSID arbitration case of Austopusta Concesionada De Venezuela, CA v Bolivarian Republic of Venezuela.$^{25}$ In this case, the arbitral tribunal adopted a similar analysis of the definition of investment in the context of the ICSID Convention. The investment dispute arose over a highway concession contract awarded to an international consortium through the Venezuelan Ministry of Transportation, which later became the Ministry of Infrastructure. The majority shares of the consortium were owned by a Mexican parent company but were later validly transferred to a United States Corporation now represented by the Claimant as its subsidiary. ${ }^{26}$

The Claimant was organized under the laws of the Republic of Venezuela. Under the concession contract, the Claimant was granted the exclusive right to design, construct, operate, exploit, conserve and maintain the Caracas-La Guaira highway and the Caracas-La Guaira old road. The investment dispute arose over disagreements regarding the implementation of the toll increases pursuant to the relevant clauses of the agreement. The Claimant was permitted to collect tolls generated by the constructed highway over a 30 -year period. ${ }^{27}$ Failing to resolve

23 Ibid.

24 J. K. Jackson, "Foreign Investment, CFIUS, and Homeland Security: An Overview"(2011) Report prepared for Members and Committee of Congress available at <http://digital.library.unt.edu/ark:/67531/metadc99132> accessed 10 August 2017

25 Austopusta Concescionada De Venezuela $v$ Bolivarian Republic of Venezuela (ICSID Case No. ARB/00/05, Decision on Jurisdiction 27 September 2001) available at<http://www.worldbank.org/icsid/cases> accessed 10 August 2017.

26 ibid para 18-25.

27 para $12-13$. 
the dispute through diplomatic intervention and a prior conciliation proceeding, the Claimant filed a request for ICSID arbitration.

In analysing the jurisdiction of the arbitral tribunal under the ICSID Convention, this arbitral tribunal notedthat "consent in and of itself" is insufficient to assume jurisdiction. Furthermore, in analysing the requirements of Article 25 that includes its analysis of the definition of investment, this tribunal expressed the view that the ICSID Convention lacks any objective requirements for the definition of investment. ${ }^{28}$ Assuming the definition of investment was specifically contended in this case, it is likely that based on the principles propounded by this arbitral tribunal with reference to the objective requirements of Article 25 , this arbitral tribunal may have defined investment in a way that is consistent with the purpose of the ICSID Convention.

On the other hand, in the more recent case of Mr Saba Fakes $v$ The Republic of Turkey ${ }^{29}$ the ICSID tribunal took a different approach in its definition of investment. It held that that the definition of investment with respect to the ICSID Convention precludes the notion that a contribution to the economic development of the host State is part of the criteria to define the term. The arbitral tribunal reached the conclusion that there is no "investment" in the present case because the Claimant does not hold a valid title to the shares in issue to justify an "investment" within the meaning of Article 25(1) of the ICSID Convention. ${ }^{30}$

The arbitral tribunal appears to be conflicted in its own analysis of the definition of investment as it pertains to contribution to the host's State economic development. It opined that the definition of investment should be by criteria, "within the framework of the ICSID Convention" without disregarding its purpose, but rejected the criterion of contribution to economic development of the host State even though the arbitral tribunal agreed that ... "the economic development of a host State is one of the proclaimed objectives of the ICSID Convention..." 31

28 para $96-97$.

29 Mr. Saba Fakes $v$ The Republic of Turkey (ICSID Case No. ARB/07/20, Award of 14 July 2010 available at <http://www.worldbank.org/icsid/cases > accessed 15 July 2017.

30 ibid para 135.

31 ibid para 110-111. 
The tribunal became more unconvincing when it stated in this ruling that, "the need for international co-operation for economic development", as stated in the preamble ICSID Convention, does not justify making acontribution to economic development "an independent criterion" for the definition of an "investment."While this arbitral tribunal may find support in some ICSID tribunal on the reasoning of its conclusion, ${ }^{32}$ the history of the ICSID Convention was negotiated to promote economic development in less developed countries through guarantees that include ICSID aimed at the protection of foreign investments abroad.

It may be argued that there is no basis in the ICSID Convention to support the proposition that contribution to the economic development of the host State is an element that should be included when defining investment under the ICSID Convention. Nevertheless, it is contended that this proposition is unnecessary. Whether the notion of contribution to the economic development of the host State is a necessary element in the definition of "investment" as envisaged in the preamble of the ICSID Convention makes it more imperative for the question to be considered independently. Williams and Foote's agreement with the reasoning of the Victor Pey Casado's award tribunal as being firm and persuasive appears not to be supported by the ICSID Convention. More so, the commentators did not provide any supporting analysis of that arbitral tribunal's reasoning to support their position. ${ }^{33}$

In the light of the preceding analysis, the first attempt to define investment to fill the lacuna created by the omission in the ICSID Convention was made in the ICSID arbitration in Fedax NV $v$ The Republic of Venezuela ${ }^{34}$ as a means to determine the outer limits of

32 See for e.g., BayindirInsaatTurizmTicaretVeSanayi A.S v Islamic Republic of Pakistan, (ICSID Case No. ARB/03/29, Award of 27 August 2009) available at <http://www.worldbank.org/icsid/cases> accessed 29 July 2017, para 145. See also Saipem S.P.A v The People's Republic of Bangladesh, ICSID Case No. ARB/ 05/07 Decision on Jurisdiction and Recommendation on Provisional Measures, 27 March 2007 available at <http://www.worldbank.org/icsid/cases > accessed 29 July 2017 with a similar proposition. (The view of these arbitral tribunals was instructive in their respective definition of "investment" pursuant to the ICSID Convention. This line of thought reinforces the inconsistency associated with the definition of "investment" under the ICSID Convention).

33 See Williams and Foote (n 8) 54.

34 Fedax N.Vv The Republic of Venezuela, (ICSID Case No. ARB/96/3, Decision of the Tribunal on Objections to Jurisdiction of 11 July 1997) available at < http:/ /www.worldbank.org/icsid/cases> accessed 30 July 2017. 
ICSID investment. Prior to the attempt made by the Fedax NV Tribunal, Schreuer laid down what is largely considered as the intellectual foundation for an alternative proposition to resolve the controversy surrounding the definition of investment in the ICSID Convention. ${ }^{35}$ Schreuer advocated five criteria that must be present for a transaction to constitute an "investment" under the ICSID Convention. These criteria are (i) a certain duration, (ii) a regularity of profit and return, (iii) an assumption of risks by both parties, (iv) significant financial commitment by the investor, and (v) a contribution to the development of the host State. ${ }^{36}$ The approach propounded by Schreuer was first considered and adopted by the Fedax tribunal. In the Fedax case, the investment dispute arose over promissory notes issued by the Respondent as a certain debt instrument in favour of the Claimant.

The arbitral tribunal examined Article 25(1) of the ICSID Convention and held that its broad scope and prior ICSID case law is consistent to "require a finding that the Center's jurisdiction and its own competence are well founded." 37 It concluded that loans and the purchase of bonds qualify as an investment within ICSID jurisdiction.

This case became the foundation for the proposition that based on the existence of certaincharacteristics; an investmentwas readily recognizable irrespective of the inherent difficulty associated with the definition of the term. The methodology adopted by the Fedax tribunal in the definition ofinvestment has been termed, "the typical characteristics approach", ${ }^{38}$ which is distinguishable from an objective approach that supports a cumulative identification of prescribed characteristics that should justify the existence of an investment on a case by case basis. Some scholars and tribunals alike have credited this approach to the Salini Criteria. ${ }^{39}$

35 E. Lanterpacht, "Christop Schreuer: An Appreciation" in C Binder, U. Kriebaum, A. Reinisch and S. Wittich (eds), International Investment Law for the 21st Century: Essays in Honor of Christoph Schreuer (Oxford University Press, Oxford 2009) 1-5.

36 C. Schreuer, The ICSID Convention: A Commentary (Cambridge University Press, Cambridge 2001) para 119-122.

37 Fedax case (n 34) para 29.

38 See A. Martin, "Definition of Investment: Could a Persistent Objector to the Salini Tests be found in ICSID Arbitral Practice?" (2011) 11 Global Jurists 1.

39 See for e.g. Alex Grabowski, "The Definition of Investment under the ICSID Convention: A Defense of Salini" (2014) 15 (1) Chicago Journal of International Law 287-309; J.M. Boddicker, "Whose Dictionary Controls?: Recent Challenges to the term "Investment" in ICSID Arbitration" (2010) 25 No. 5 American 


\section{THE SALINI CRITERIA}

The Salini criteria emerged from the case of Salini Construttori SPA and Italstrade SPA $v$ Kingdom of Morocco. ${ }^{40}$ This tribunal's attempt to define investment elevated the "typical characteristics" approach of the FedExTribunal to a distinct jurisdictional requirement. Schreuer, upon whose thesis the decision was based, cautioned that the Salini criteria should not be seen as distinct jurisdictional requirement each of which must be met separately with reference to the definition of investment. ${ }^{41}$

The ICSID arbitration, in this case, arose from a contractual dispute over the construction of a highway by a foreign investor in Morocco. One of the issues raised by the Respondent was that the transaction was not an investment under the ICSID Convention to justify ICSID arbitration. ${ }^{42}$ The Claimant argued that the reference to the host State law, in this case, is only a means to realize the investment and not to define it. Faced with limited ICSID precedents on the definition of investment, except for the approach adopted in the Fedax Tribunal, this Tribunal relied largely on the scholarly work of Schreuer and defined in investment this way:

... The doctrine generally considers that investment infers: Contributions, certain duration of performance of the contract and participation in the risks of the transaction. In reading the Convention's preamble, one may add the contribution to the economic development of the host State as an additional condition...

Proponents describe the Salini criteria as an objective approachthat supports the proposition that investment under the ICSID Convention

University International Law Review 1031-1071; and B. Crina, "Precedent on Notion of "investment": ICSID Award in MHS v. Malaysia" (2007) 4, 5 Transnational Dispute Management 1-5.

40 Salini Construttori S.P.A and Italstrade S.P.A v Kingdom of Morocco (ICSID Case No. ARB/00/4, Decision on Jurisdiction 23 July 2001) available at $<$ http:// italaw.com/cases/documents/959> accessed 1 September 2017. See also Felix O. Okpe, "Economic Development and the Utility of Local Content Legislation in the Oil and Gas Industry: Conflicts and Effects of Nigeria's Local Content Act in the Context of International Investment Law" (2015) 28 (2) Pacific McGeorge Global Business and Development Law Journal 255, 285-294.

41 C. H. Schreuer with L. Malintoppi, A Reinisch and A Sinclair, The ICSID Convention: A Commentary (2nd edn, Cambridge University Press 2009)133.

42 Salini Case (n 40) para 40. 
has a standard meaning that is discernible following the criteria. This way, the criteria created some cumulative requirements to define an investment under the ICSID Convention. ${ }^{43}$ In contrast, the typical characteristics approach of the Fedaxarbitral tribunal may not lead to the determination of an investment where one or more of the established hallmarks are absent.

Based on this analysis of the distinction between the Fedax/Salini criteria, the Malaysian Historical Salvors arbitral tribunal dismissed the differences between the two approaches. ${ }^{44}$ The arbitral tribunal based its reasoning on the premise that, "[t]he classical Salini hallmarks are not a punch list of items, which if completely checked off, will automatically lead to a conclusion that there is an investment. ${ }^{45}$

Williams and Foote did not support the prescriptive analysis adopted by this arbitral tribunal. Instead, the authors opined that "the Malaysian Salvors tribunal approach arguably stopped short of the socalled jurisdictional approach ... At least, however, it appears to elevate the FedEx/Salini criteria to a presumption." ${ }^{6}$ The authors hinged their scepticism on the principlethat, "no one prospective investment is likely to be exactly as another". ${ }^{47}$ The authors then wondered whether such an approach is "appropriate where the possible features of financial commitment by Claimants are as infinite as the field of human endeavour." 48

Critics of the "jurisdictional requirements approach" made famous by the Salini tribunal, advocate a subjective approach that recognizes and upholds the consent and agreement of the State party and investor in the definition of investment as understood under the ICSID Convention. ${ }^{49}$ In this regard, subjectivity juxtaposed with the input of

43 R. Happ and N. Rubins, Digest of ICSID Awards and Decisions 2003-2007 (Oxford University Press, Oxford 2009) 341-342. The authors noted that the Salini"criteria have been used frequently during the 2003-2007 period as an indicator that an investment exists for ICSID purposes".

44 Malaysian Historical Salvors, SDN, BHD v. Malaysia (ICSID Case No. ARB/05/10, Decision on the Application for Annulment of 16 April 2009) available at <https:/ /icsid.worldbank.org/ICSID/FrontServlet?requestType=CasesRH\&actionVal= viewCase \&reqFrom $=$ Home\&caseId $=\mathrm{C} 247>$ accessed 18 February 2017 para 106(e).

45 Ibid.

46 William and Foote (n 8) 52.

47 Ibid.

48 Ibid.

49 T. Cole and A. K. Vaksha, "Power Conferring Treaties: The Meaning of Investment in the ICSID Convention” (2011) 24 Leiden Journal of International Law 305, 315. 
the State party and the investor, evident from their consent and agreement may lead to a more predictable approach to the definition of investment. It has been suggested that "a rigid list of criteria that must be met in every case is not likely to facilitate the tasks oftribunal or to make decisions more predictable." 50

The Salini criteria have been criticized by subsequent ICSID arbitration tribunals as a formalization of the definition of investment that could conflict with the agreement of the State party and foreign investor on the definition of "investment". ${ }^{51}$

It may be argued that in the Biwater Gauff case, the arbitral tribunal's reference to "the parties" in paragraph 317 of the award connotes the "Contracting Parties" under the applicable investment treaty when paragraph 317 is read in the light of paragraph $312 .{ }^{52}$ In paragraph 317, the arbitral tribunal was referring to the host State and the foreign investor as parties to the ICSID arbitration; otherwise, it would have specifically referred to the 'Contracting Parties'. Based on the nature of ICSID arbitration, the foreign investor adopts the agreement of his home country in an investment treaty once theinvestment is made in the territory of the host State party to the treaty.

The Biwater Gauff arbitral tribunal was requested to determine whether the subject matter of the arbitration was an "investment". The arbitral tribunal examined the legislative history of the ICSID Convention, hence the tacit reference to Article 24(4) in paragraph 312. Paragraph 312 can only be read in the light of paragraph 317 only to the extent that it grants opportunity to the parties to the dispute to define investment in view of the omission in the ICSID Convention. Pursuant to the ICSID Convention and the applicable investment treaty, the host State and the foreign investor can be parties to a dispute in ICSID arbitration, likewise the State parties to the investment treaty.

50 C. H. Schreuer et al (n 41) 172.

51 See for e.g. Biwater Gauff (Tanzania) Ltd v Tanzania, (ICSID Case No. ARB/05/ 22 Award of 24 July 2008); Ceskoslovenska Obchodni Banka, A.S. v The Slovak Republic (ICSID Case No. ARB/97/4, Decision on Jurisdiction of 24 May 1999) available at http://www.worldbank.org/iscid/cases assessed 22 May 2017; and Republic of Albania (ICSID Case No. ARB/07/21, Award of 30 July 2009) available at <http/www.worldbank.org/icsid/cases > accessed 26 June 2017.

52 Biwater Gauff (Tanzania) Ltd v Tanzania, (ICSID Case No. ARB/05/22 Award of 24 July 2008) para 312, the arbitral tribunal stated that, "[i]n the end, the term was left intentionally undefined with the expectation that a definition could be the subject of agreement as between Contracting States." 
It is doubtful that anytime an arbitral tribunal references the legislative history of the ICSID Convention or an investment treaty concluded by State parties, the foreign investor is automatically excluded or substituted as a party to the dispute with the result that any reference to "the parties" in the analysis of the claims exclusively refers to State parties to investment treaties or the ICSID Convention. In the alternative, it may be argued that based on the individual contract and the investment treaty that was examined by the Biwater Gauff arbitral tribunal, it is unclear which "parties" the arbitral tribunal was referring to in paragraph 317. Ultimately, any likely proposition in the award under review may be applicable mutatis mutandis to the host State and the foreign investor.

Reacting to the criticism of the Salini criteria, Schreuer appears to note in agreement when he stated that: "[t]hese features should not necessarily be understood as jurisdictional requirements, but merely as typical characteristics of investments under the Convention." 53

Arbitral tribunals have demonstrated a lack of consensus on the application of the Salini criteria. ${ }^{54}$ The subjective approach, which is founded on contractual freedom of the parties, has not been successful in establishing a generally acceptable definition of investment under the ICSID Convention. ${ }^{55}$ Applying the Salini criteria could lead to challenging the jurisdictional requirements of the ICSID Convention as a matter of law. ${ }^{56}$ This is because the Salini criteria are "not a formal requirement for the finding that a particular activity or transaction constitutes an investment."57

One opponent of the Salini criteria suggested that a "persistent objector" to the Salami criteria is possible. ${ }^{58}$ According to this commentator, a persistent objectoris a party who reserves the right to question the Salini criteria as a matter of law because the ICSID Convention does not support its jurisdictional value. ${ }^{59}$ This

53 See Schreuer (n 41) para 122.

54 See BiwaterGauff (Tanzania) v Tanzania (n 52).

55 For e.g. see CMS Gas Transmission Co. v Argentina (ICSID Case No. ARB/01/8, Decision on the Application for Annulment, 25 September 2007) para 7172.available at <http://www.worldbank.org/icsid/cases > accessed 30 April 2017.

56 A. Martin (n 38) 2.

57 ibid.

58 A. Martin (n 38) 17.

59 ibid. 
commentator suggested that the findings of the Fedax/Salini arbitral tribunals are apposite, regardless of the inherent notion of contractual freedom that may be gleaned from both decisions.

The same commentator notes that the Fedax arbitral tribunal merely presented a list of features that might make "investment" recognizable pursuant to the ICSID Convention, while the Salini tribunal, "established a list of formal requirements conditioning a finding of jurisdiction" to satisfy the requirements of Article 25 (1) with reference to the definition of "investment". The commentator rejected the nuances of the Fedax/ Salini criteria and argued, instead, that the contractual freedom to define "investment" as a strong presumption under the ICSID Convention seems more convincing, otherwise "a persistent objector to the Salini criteria may be found." 60

ICSID arbitration jurisprudence reveals a mixture of considerations of the definition of investment under national foreign investment legislation and applicable investment treaties.To be clear, in situations where there is no applicable investment treaty, the host State's foreign investment legislation, such as the NIPC Act in the case of Nigeria, becomes dominant in the definition of investment as a gateway to ICSID arbitration.

\section{THE DEFINITION OF INVESTMENT UNDER THE NIPC ACT}

The definition of investment under the NIPC Act is critical because of Nigeria's ratification and consent to ICSID arbitration within the framework of the ICSID Convention and the operative effect of Section 25 (2) (b) (c) of the NIPC Act. ${ }^{61}$ In this respect, the definition of "investment" is relevant in cases where there are no applicable investment treaties regulating the conduct of the foreign investor's investment in Nigeria. Arbitral practice is consistent with the view that, where there is a conflict between a national investment legislationand an applicable investment treaty on the definition of investment, the consideration under the investment treaty prevails. ${ }^{62}$

60 ibid 17.

61 NIPC Act (n 3).

62 Emilio Agustin Maffezini $v$ The Kingdom of Spain (Decision on Objections to Jurisdiction of 25 January 2000) 5 ICSID Reports 389-390. 
This position is influenced by the notion that investment treaties offer better protection of foreign investments in the host state.

Damrosch et al. reported that "international tribunals have sometimes declared municipal legislations to be subject to international obligations." 63 The authors" observation is based on the idea that the host State is bound to give effect to the principles of international law. ${ }^{64}$ Consideration for the investment of private international capital directly in the host State is usually influenced by the assurances in place for the protection of foreign investments. These assurances may be useless, ambiguous or ineffective in the absence of a definition of investment that incorporates the protected investment.

With reference to foreign investment in developing countries, Landau appears to argue that based on the considerations for the protection of foreign investment in these countries, the foreign investor must be made aware that his investment ought to contribute to economic development. ${ }^{65}$ Landau's proposition on the need for a welldefined "standard of responsibility"on the part of the host State for the protection of foreign investment ought to include a reciprocal responsibility on the foreign investor to ensure the realization of the purpose of his investment from the perspective of the host State. ${ }^{66}$ In view of the lack of a consensus on the definition of "investment" under the ICSID Convention and ICSID jurisprudence, it is argued that the inherent inconsistency on the issue has had a trickledown effect on the notion of "investment" under the NIPC Act in an attempt to seize the opportunity presented by Article 25 (4) of the ICSID Convention. Clearly, the ICSID Convention and arbitral tribunals have offered no guidance.

The NIPC Act was passed into law to promote FDI in Nigeria. The NIPC is vested with authority to initiate, coordinate, support, and monitor all FDI-related activities to which the NIPC Act applies. The NIPC can also invite foreign investors to participate in specific projects identified by the Commission.

Section 31 of the NIPC Act defines investmentas a financial- or resource-based transaction made to acquire an interest in an enterprise

631 L. F. Damrosch, L. Henkin, R. C. Pugh, O. Schachter and H. Smit, International Law: Cases and Materials (Fourth edn. West Group, 2001) 161.

64 ibid 159.

65 H. Landau, "Protection of Private Foreign Investment in Less Developed Countries: Its Reality and Effectiveness" (1968) 9 William and Mary Review 804. 66 ibid 822. 
operating within or outside Nigeria. Investment by foreign investors in any enterprise operating outside Nigeria is not advantageous as an investment in the context of FDI. Under international investment law, FDI is conceptualized to be in the territory of the host State to contribute to economic development. The definition of investment under the NIPC Act is, therefore, amorphous, too broad, and ubiquitous.

For example, a multinational like Shell Petroleum Development Company of Nigeria Limited (SPDC) can use an investment claim arising from its investments in Nigeria to claim against any adverse effect on its operations outside Nigeria. ${ }^{67}$ In this instance, investments without a direct territorial nexus to Nigeria are a protected investment under Section 26(2)(b)(c) of the ICSID Convention. Two ICSID arbitral tribunals $^{68}$ have held the view that, with respect to investment dealing with the transfer of funds, an arbitraltribunal should not decline jurisdiction because there is no evidence of physical transfer of funds. Both ICSID cases had similar fact pattern. The Respondents had argued that the disputed transactions were not investments made within their territory and should not be protected by the ICSID Convention but the arbitral tribunals disagreed. However, in the later analogous ICSID arbitration case of Bayview Irrigation District et al. $v$ United Mexican States, ${ }^{69}$ the arbitral tribunal declined jurisdiction on the ground that the Claimant had not made an investment in the territory of the Respondent host State. ${ }^{70}$ The question of whether or not investments should be made "in the territory" of the host State can be controversial because there are varying forms of investments in the context of ICSID arbitration. ${ }^{71}$

\section{RECOMMENDATIONS}

The NIPC Act should be reviewed and narrowed to require protected FDI be made within the territory of Nigeria. This will make it clearer

67 Shell Global owns SPDC with headquarters in The Netherlands. Shell Global is a multinational foreign investor in Nigeria with operations all over the world.

68 Fedax Case (n34) and CSOB v The Slovak Republic, (ICSID Case No. ARB/97/4, Decision on Jurisdiction of 24 May 1999) 5 ICSID Reports 335.

69 Bayview Irrigation District et al. $v$ United Mexican States, (ICSID Case No. ARB (AF)/05/1, Award of 19 June 2007) available at < http://www.worldbank.org/ icsid/cases $>$ accessed 20 June 2017.

70 ibid para 101-108.

71 See C. Knahr, "Investments in the Territory of the Host State" in C Binder et al (eds), International Investment Law for the 21st Century: Essays in Honour of ChristophSchreuer (Oxford University Press, 2009) chapter 5. 
that the fundamental purpose of the NIPC Act is to attract FDI to aid economic development. Such a definition of investment resolves the territorial question of FDI and makes the element of contribution to economic development critical in the definition of investment under the NIPC Act.

It is arguable that the provision of Section 4 (c) of the NIPC Act, to "promote investments in and outside Nigeria through effective promotional means" covers investment outside Nigeria. However, that section of the NIPC Act is only a directive to the NIPC to utilize promotional means within and outside Nigeria to attract FDI to the Nigerian economy. Section 4(c) of the NIPC Act cannot pass as a justification of the amorphousand ambiguous definition ofinvestment under the NIPC Act.

Furthermore, when section 31 is read considering Section 26(2) (b) of the NIPC Act, it creates uncertainty on the scope of the consent to ICSID arbitration by Nigeria. It is unclear whether the offer to arbitrate investment claims pertains to an "enterprise", an "investment" or both. The ICSID dispute settlement procedures under the NIPC Act refer to disputes that arise "between an investor and any Government of the Federation in respect of an enterprise" not an "investment" per se. The definition of "enterprise" 72 under the NIPC Act is broader than the definition of "investment" under the same Act.

The inflow of FDI within the framework of the NIPC Act presents Nigeria as the host State. The nature of the foreign investment dispute is described as "... one between an investor from one country and a government that ... relates to an investment in the host country. ${ }^{73}$ In other words, under the international investment law regime, a foreign investment is envisaged to be an investment in the territory of the host State, not outside it. ${ }^{74}$ It is contended that the definition of investment under the NIPC Act is in conflict with the jurisdictional

72 See NIPC Act (n 3) Section 31. The section defines an "enterprise" to "mean an industry, project, undertaking, or business to which this Act applies or an expansion of that industry, undertaking, project or business, or any part of that industry, undertaking, project or business and where there is foreign participation, means such an enterprise duly registered with the Commission."

73 R. Bishop, J. Crawford \& W. M. Reisman, Foreign Investment Disputes: Cases, Materials and Commentary (Kluwer Law International, 2005) 9.

74 "Economic Development at the Core of the International Investment Law Regime" in C. Brown and K. Miles (eds), EvolutioninInvestment Treaty Law and Arbitration (Cambridge University Press, Cambridge 2011) 587. 
requirements of Article 25(1) of the ICSID Convention. Article 25(1) of the ICSID Convention defines the jurisdiction of the Center to extend to legal disputes arising out of an investment between a contracting State and the national of another contracting State. The legislative intent might be to provide a broader definition of investment that extends to any conceivable economic activity to attract foreign investment because the same section of the NIPC Act defines "enterprise" to include any conceivable economic activity by a foreign investor.

Ekwueme ${ }^{75}$ was swift to embrace this definition of investment as being advantageous in the Nigerian context. He arguedthat the "nebulous" definition of "investment" under the NIPC Act creates a unique flexibility that would facilitate and accommodate the excogitating nature of theinvestment. Thus, re-investment returns on foreign investment satisfy the requirement of "investment" under the NIPC Act.

The present author disagrees with Ekwueme. The definition of investment under the NIPC Act is not advantageous in the manner described by the commentator. The point is not lost that, the purpose of the ICSID Convention is to create the opportunity for international cooperation for economic development through private international investments. ${ }^{76}$ Contribution to economic development is the best stream through which Nigeria can achieve its legitimate expectation in the conduct of FDI. In the light of the inconsistent ICSID jurisprudence on the definition of investment and the less than favorable consideration of contribution to economic development element in the definition of investments by arbitral tribunals so far, the definition of investment under the NIPC Act puts Nigeria at a disadvantage if the definition of investment under the NIPC Act is tested by ICSID arbitration. It becomes very difficult to agree with Ekwueme that the definition of investment under the NIPC Act is beneficial to Nigeria's legitimate expectation in the conduct of FDI underthe NIPC Act.

\section{CONCLUSION}

A consistent approach to the meaning of investment within the framework of the ICSID Convention and international investment law

75 1Ekwueme (n 4) 181.

76 Preamble of ICSID Convention (n 1). 
could have provided a concrete guidance on the meaning of the term for State parties to achieve their expectations in the international investment regime. The inconsistent jurisprudence of ICSID arbitral practice on the definition of investment means that Article 25 (1) of the ICSID Convention remains ambiguous. It is this ambiguity in the definition of investment that has found its way into the NIPC Act.

The effect of this ambiguity and broad approach that brings every conceivable foreign investment under the FDI canopy can be dire for a developing country caught off guard because of an amorphous definition ofinvestment. Awards against host states in ICSID arbitration are often enormous and can negatively affect the GDP of most developing countries.Ultimately, the nature of the definition of investment under the NIPC Actcan erode Nigeria's capacity to bind itself and its substantive promises to protect foreign investment may have no convincing effect on potential foreign investors.

85 Tizikara, C., and Lugor, L.G.L., Post-Conflict Development of Agriculture in South Sudan; Perspectives on Approaches to Capacity Strengthening (Ministry of Agriculture od South Sudan, Juba) http://www.erails.net/images/fara/ secretariat/kigali-movement/file/Kigali\%20Movement/South\%20Sudan.pdf 86 Ibid.

87 ibid. 